Grażyna Ewa Karpińska

ORCID: https://orcid.org/0000-0003-2102-774X

Instytut Etnologii i Antropologii Kulturowej

Wydział Filozoficzno-Historyczny

Uniwersytet Łódzki

\title{
Udomowianie ulicy. Z etnograficznych badań terenowych na Wschodniej
}

\section{Taming a street. From the ethnographic field research at Wschodnia Street}

\begin{abstract}
The article describes the practices aimed at developing a sense of settlement at a street and the methods by which concrete persons and communities imbue the physical entity of a street with a value and a symbolic meaning. The analysis is based on materials collected among the owners of craftsman's workshops located along one of the streets in the city of Eódź, namely Wschodnia Street. The street was laid out in the early $19^{\text {th }}$ century, concurrently with the development of Łódź as an industrial town; by the outbreak of the 1st World War it had been filled with low-standard tenements containing rented lodgings on the upper levels and retail space on the ground floor. At the turn of the $19^{\text {th }}$ century it was already a street of merchants and craftsmen, and it retained this outlook until the end of the $20^{\text {th }}$ century. Today, it lies within an old, dilapidated and decaying area of Łódź, its residents are impecunious and the shops are closing.
\end{abstract}

Key words: a sense of settlement at a street, spatial practices, place, Wschodnia Street, Łódź

W artykule opisuję praktyki budujące poczucie zadomowienia ulicy, przedstawiam sposoby, w jakich ulica, będąca fizycznym bytem, uzyskuje wartość i znaczenie symboliczne dla konkretnych osób i wspólnot. Opieram się na materiałach zebranych od właścicieli zakładów rzemieślniczych zlokalizowanych na jednej z ulic w Łodzi - ulicy Wschodniej. Ulica ta została wytyczona wraz z powstaniem Łodzi jako przemysłowego miasta na początku XIX wieku, do I wojny została zabudowana czynszowymi kamienicami niskiego standardu, których partery przeznaczano na sklepy. Już na przełomie XIX i XX wieku miała charakter ulicy handlowej i rzemieślniczej, który utrzymywała do końca XX wieku. Dziś jest fragmentem starego, zdekapitalizowanego i zaniedbanego obszaru Łodzi, który zaludniają osoby ubogie, a sklepy są zamykane.

Słowa kluczowe: zadomowianie ulicy, praktyki przestrzenne, miejsce, ulica Wschodnia, Łódź

Odebrano / Received: 31.01.2019

Zaakceptowano / Accepted: 27.08.2019 
Termin „zadomowienie” ma korzenie w słowie „dom”, którego źródłosłów jest związany z tworzeniem i budowaniem ${ }^{1}$. Hanna Buczyńska-Garewicz pisze, że domem nazywamy takie miejsce, w którym przebywanie „nabiera cech bliskiego zaznajomienia, zżycia z miejscem”. Zwraca też uwagę, że pojęcie „dom” nie mówi o samodzielnej przestrzeni, lecz o „określonym sposobie [wyróżnienie G.E.K.] znajdowania się gdzieś”, a początek tworzenia domu jest wyrażony przez „stosunek człowieka [wyróżnienie G.E.K.] do pewnej wyróżnionej przestrzeni”". Mary Douglas podkreśla, że dom nie musi być nierozerwalnie związany z przestrzenią; powstaje on wówczas, gdy obejmujemy nad nią władzę . Takie stanowiska badaczek zachęcają do przyjrzenia się temu, co decyduje, że dana przestrzeń pozadomowa zostaje udomowiana oraz jakie aktywności przestrzeń pozadomową udomowiają.

W artykule opisuję praktyki udomowiające ulicę Wschodnią w Łodzi. Ulica jest konkretną przestrzenią fizyczną w mieście, lecz z „fenomenologicznego punktu widzenia wyraża jednocześnie wiele rodzajów miejsc - w zależności od tego, przez kogo jest

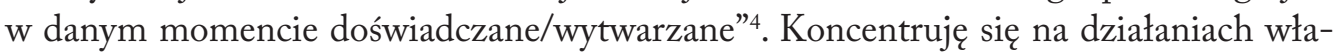
ścicieli zakładów rzemieślniczych znajdujących się na Wschodniej. W relacjach autobiograficznych, zebranych przeze mnie w trakcie etnograficznych badań terenowych w latach 2015-2018, zawarte są doświadczenia przestrzeni ulicy, historie miejsc i ludzi oraz opisy zdarzeń. Wschodnia, o której opowiadali rozmówcy, składa się z miejsc dostępnych tylko w ich pamięci ${ }^{5}$, albowiem opisywali ją z perspektywy tego, co przeżyli, a to oznacza przefiltrowanie ulicy przez własne doświadczenia i doznania zmysłowe. Ulicę Wschodnią zachowaną w opowieściach rzemieślników od lat mających tu swoje miejsca pracy - poddaję „umyślnej praktyce przestrzennej”, jak by ją określił Michel de Certeau, czyli retoryce imaginowanego spacerowania określonymi trasami. Mnogość tras wkomponowuje się w „kartografię pamięci” mającą charakter subiektywny i podporządkowanej indywidualnemu doświadczeniu'.

Ulica Wschodnia, wytyczona w latach 20. XIX stulecia w trakcie powstawania osady sukienniczej Nowe Miasto, do 1915 roku została w całości zabudowana domami czynszowymi niskiego standardu, z których większość ma rodowód dziewiętnastowieczny. Partery kamienic frontowych przeznaczano na nieduże sklepy i zakłady rzemieślnicze; w każdym domu znajdowało się ich od dwóch do czterech, co nadawało ulicy handlowo-rzemieślniczy charakter. Również i dziś na Wschodniej można zreperować zegarek, uszyć lub przerobić spodnie, kupić kapelusz lub czapkę, choć usługi te należą do zanikających. Pracownię modniarską, zakłady zegarmistrzowskie i krawieckie prowadzą

\footnotetext{
1 Benedyktowicz, Benedyktowicz 1992, s. 7.

2 Buczyńska-Garewicz 2006, s. 129.

3 Douglas 1991, s. 289.

4 Pink 2008, s. 179.

5 Czermińska 1978, s. 247.

6 Saryusz-Wolska 2011, s. 152-156.
} 
osoby będące rzemieślnikami $\mathrm{w}$ drugim pokoleniu, niektórzy z ulicą są związani od urodzenia.

Ulica to jeden z elementów miejskiego pejzażu, który tylko pozornie nie jest nacechowany emocjonalnie. „To jest moja Wschodnia”, „Tutaj na Wschodniej jest samo życie, tu jest szczera prawda, okrutna prawda. I ja stąd nie zamierzam odejść”, „Mój mąż mówi: Ty bez tej Wschodniej to żyć nie możesz. No nie mogę. Ale to robią lata, bo to jest to zżycie się" - tak rezydenci ze Wschodniej „ucieleśniali lingwistycznie” (termin Davidson, Milligan ${ }^{7}$ ) swoje poczucie więzi i emocje związane $z$ ulicą. Ich relacje autobiograficzne, mimo odmienności w przebiegach indywidualnych losów, mają wspólny mianownik, jakim są osobiste i wieloletnie doświadczanie ulicy i związanych z nią miejsc oraz emocjonalne interakcje formujące struktury „wyjątkowych personalnych topografii". Jak pisał Keith Basso, zmarły niedawno amerykański antropolog, relacja między miejscem a jego użytkownikami wynika ze „wzajemnego pobudzania”, co znaczy, że ludzie ożywiają miejsce przez doświadczanie, emocje i pamięć siłą równą tej, z jaką owo miejsce indukuje owe przeżycia ${ }^{9}$. Wzajemne wspólistnienie i współformowanie, a przede wszystkim konstytutywny dla przestrzeni sposób istnienia człowieka, czyli rozumiejący sposób przebywania człowieka w miejscu, Hanna Buczyńska-Garewicz nazywa mieszkającym zadomowieniem ${ }^{10}$. Zobaczmy zatem, jak wyglądało owo mieszkające zadomowianie ulicy Wschodniej.

Wszyscy moi rozmówcy opowiadali jakąś historię swojego początku „obcowania” z ulicą, a było nim albo dzieciństwo, albo podjęcie tu pracy w młodzieńczym lub dorosłym życiu, zawsze kończące się przejęciem zakładu po rodzicach. W ich opowieściach obecna jest zatem wspomnieniowa perspektywa poprzedniego pokolenia, które na Wschodniej zaczynało prowadzić działalność rzemieślniczą zaraz po II wojnie światowej. Już sama dziedziczność zawodu i prowadzenia zakładu dały rozmówcom poczucie stabilizującej przynależności, bo porządkując nić życia - generacyjny depozyt - wzmocniły poczucie osiadłości na Wschodniej i więź z ulicą, co jest jednym z elementów procesu zadomowiania każdej przestrzeni.

Najpierw przedstawię tych, którzy są związani ze Wschodnią od urodzenia.

Pan Bogdan (zakład krawiecki, Wschodnia 25) urodził się w 1941 roku na Wschodniej. Jego rodziców Niemcy wysiedlili z ulicy Leśnej, kiedy organizowali teren pod getto. Zamieszkali w oficynie kamienicy pod numerem 25, na drugim piętrze. Rodzice pana Zbyszka (zegarmistrzostwo, Wschodnia 27) przyjechali do Łodzi w czasie wojny z Poznania. Zamieszkali niedaleko Wschodniej, w kamienicy na Rewolucji 1905 roku - wtedy to była ulica Południowa - pod numerem 21. Tu pan Zbyszek urodził

\footnotetext{
${ }^{7}$ Davidson, Milligan 2004, s. 523.

${ }^{8}$ Davidson, Milligan 2004, s. 523.

${ }^{9}$ Basso 1996, 56-57, za: Gnieciak 2011, s. 64.

${ }^{10}$ Buczyńska-Garewicz 2006, s. 42.
} 
się w 1943 roku. Dla obu mężczyzn ulica Wschodnia i okolice to przestrzenie ich dzieciństwa przypadającego na lata 40. i 50. XX wieku, to miejsca przez nich wybrane i akceptowane do różnych eksploracji, miejsca, w których rozgrywały się ważne dla nich zdarzenia. Były to zabawy z kolegami na podwórku i na ulicy przed kamienica, gonitwy po kamienicznych dachach z chłopakami z ulicy Włókienniczej - wtedy Kamiennej, podglądanie $\mathrm{z}$ dachu gołębiarzy na podwórkach Włókienniczej, poszukiwania skarbów na gruzowisku po getcie przy ulicy Północnej, obrona swego terytorium przed chłopakami z Północnej, obserwowanie ludzi i życia na Wschodniej i okolicznych ulicach.

Między domem a obszarem z nim sąsiadującym (ulica) istniały relacje wyrażające się w dialektyce wewnętrzności i zewnętrzności: dźwięki, odgłosy i zapachy z ulicy „wchodziły” do mieszkania przez otwarte okna i drzwi, natomiast dom „wychodził” na zewnątrz i stanowił cząstkę krajobrazu dźwiękowego i zapachowego ulicy ${ }^{11}$. Jednakże $\mathrm{w}$ procesie zadomowiania przestrzeni poza domem dużą rolę odgrywało jej multisensoryczne percypowanie: o specyfice miejsca i w budowaniu poczucia „bycia u siebie” decydował splot wrażeń akustycznych, olfaktorycznych i wizualnych. Należy dodać do tego doświadczanie przestrzeni - niezwykle ważny element przyczyniający się do jej udomowiania: chłopcy biegający po dachach kamienic, bawiący się na podwórku i w bramie, spacerujący po Wschodniej stwarzali określone sytuacje w czasie i przestrzeni ulicy, stawali się częścią jej krajobrazu i wytwarzali go swymi ciałami ${ }^{12}$. Ponadto, co opisuje Hugh Matthews, różnorodne sposoby „bycia na ulicy” młodszych i starszych dzieci mają decydujący wpływ na ustalanie przez nie tak teraźniejszych, jak i późniejszych relacji i pozycji w grupie, są również częścią doświadczenia końca dzieciństwa i wejścia w okres dorosłości ${ }^{13}$. Gdy po latach, już jako dojrzali mężczyźni, przejęli zakłady po śmierci ojców i powrócili w zmienioną przecież przestrzeń ulicy, nadal czuli, że są tu „u siebie”. Ulica ta, z którą zżyli się już w dzieciństwie, która „dziš” stanowi silne źródło wspomnień, a „kiedyś” była źródłem ich energii życiowej, przestrzenią dużej swobody i wolności oraz areną „robienia czegoś”, ponownie zaangażowała ich działania, emocje, marzenia, pamięć i ciała w proces dalszego jej udomowiania. Albowiem udomowianie to praktyka podlegająca ciągłym procesom renegocjacji, wytwarzania, oswajania i projektowania.

Inne doświadczanie ulicy Wschodniej i praktyki budujące poczucie zadomowienia mieli ci, którzy na Wschodnią dotarli jako osoby dorosłe. Przykładem są działania pani Marii i pani Bożeny.

Pani Maria (zegarmistrzostwo, Wschodnia 33) pracowała w urzędzie, lecz bardziej interesowało ją zegarmistrzostwo, zawód wykonywany przez jej ojca. Ukończyła więc kursy zegarmistrzowskie i od 1988 roku została zatrudniona w zakładzie ojca, prowadzącego od tej pory hurtownię zegarmistrzowską, podczas gdy ona przejęła usługi.

\footnotetext{
${ }^{11}$ Czermińska 1978, s. 232.

12 Rapior 2012, s. 149.

${ }^{13}$ Matthews 2003, 104-113.
} 
W 2003 roku, po jego śmierci, została właścicielką zakładu, który prowadziła do czasu jego likwidacji w 2017 roku.

Początkowo neutralny obraz przestrzeni (budowany z opowieści ojca z czasów, gdy miał zakład zegarmistrzowski na innej ulicy, a na Wschodnią przychodził, by kupić w jatce koninę dla psa i do znajdującej się tu hurtowni części do zegarków i zegarów) stopniowo angażuje jej nasilające się i zmieniające wobec ulicy uczucia. Gdy kobieta idzie Wschodnią do i z pracy w warsztacie zegarmistrzowskim, doznaje nie tylko fizyczności ulicy: podczas codziennego chodzenia wracały wspomnieniem zasłyszane kiedyś opowieści o ulicy, a codzienne przemieszczanie się uruchamiało oddziaływanie poznawczych skryptów kulturowych i społecznych oraz pomagało jej cieleśnie rozpoznawać habitus Wschodniej. Każdego dnia pani Maria, pokonując ten sam odcinek ulicy, mija te same osoby, stojące w tym samym miejscu:

Ta ulica zawsze była pijana, o pijanej Wschodniej zawsze mówiło się na mieście. Jak jeszcze tu nie pracowałam, pracowałam w urzędzie i jak się szło na jakąś kontrolę, to zawsze ostrzegali: <Uważajcie, bo to Wschodnia!>. Zresztą o Wschodniej, której należało się bać wszyscy wiedzieli. Po bramach stały grupki mężczyzn, masę ich stało. I pili. Ja pamiętam czasy, jak podjeżdżała policja, to na baczność stali, bo bali się jeszcze policji. Ale stali i pili. Czy ci ludzie pracowali, czy nie pracowali, nie spieszyli się do domu jak ludzie, którzy mają jakieś zainteresowanie. Oni tu nie mieli żadnego zainteresowania. Dla nich to najlepsza była w grupkach rozmowa i picie. Czasami ta młodzież też jeszcze dziś stoi, jak stali ich ojcowie, dziadkowie.

Jak ja tu przychodziłam, to prosiłam: <Tato wyjdź po mnie. Albo z tej, albo z tej, bo ja tu nie wejdę do sklepu>. I tak było stale niezależnie od pory dnia, niezależnie od pory roku, niezależnie czy to zima nie zima. Oni stali w tych bramach. Tak wyglądała Wschodnia. Teraz nie ma ich. Powymierali. Jakichś tam następców powyprowadzali wtedy na tą Ogrodową, kamienice zaczęły stawać się prywatne, zaczęli je odzyskiwać - to wyrzucali ludzi. Także też trochę zrobili porządek.

Ulica Wschodnia jest fragmentem starego, zdekapitalizowanego i zaniedbanego obszaru Łodzi, który zaludniają osoby ubogie mieszkające w starych kamienicach czynszowych ${ }^{14}$. W jego obrębie socjolodzy obserwują zaawansowany proces kształtowania się underclass, czyli społeczności biednych mieszkańców, którą cechuje „skumulowane bezrobocie, bieda przekazywana pokoleniowo i zachowania odbiegające od standardów charakterystycznych dla większości Polaków”"15 , i opisują w kategoriach gettoizacji miejskiej przestrzeni ${ }^{16}$.

\footnotetext{
${ }^{14}$ Grotowska-Leder 1999, s. 66-70.

${ }^{15}$ Grotowska-Leder 2002, s. 20.

${ }^{16}$ Warzywoda-Kruszyńska 2013, s. 61.
} 
Wchodząc we Wschodnią, pani Maria przekraczała granicę nieznanego, wyraziście innego od innych, poznanych obszarów miasta. Krajobraz ulicy wysyłał sygnały odbierane przez nią jako intuicyjnie wyczuwalne zagrożenie, określane chociażby stopniem fizycznej degradacji przestrzeni. Kobieta wchodziła w obcość, przez którą przedzierała się, rejestrując nieprzewidywalne obiekty, przede wszystkim stojących w bramach mężczyzn, „tutejszych miejscowych” pasujących do obrazu Wschodniej i z nią związanych. Ludzie ci kształtowali krajobraz ulicy i naznaczali jej przestrzeń, zaś krajobraz tego fragmentu miasta „formował rysy ich twarzy" ${ }^{17}$. W percepcji i ocenie niebezpieczeństwa pani Maria była pod wpływem społecznego waloryzowania i etykietowania ulicy („Uważajcie, bo to Wschodnia!”), które utrwalało jej nastawienie do Wschodniej.

Pani Maria odbierała sygnały rzeczywistości nie tylko wzrokowo, lecz również słuchowo. Mieszkańcy ulicy przychodzący do zakładu, by kupić lub naprawić zegarek, opowiadali jej swoje historie, ona zaś słuchała opowieści z ich codzienności przeszłej i teraźniejszej: o tym, jak pracowali w fabryce Marchlewskiego (kiedyś) i o tym, jak ciężko jest bez pracy (dziś).

Z praktykami udomowienia przestrzeni łączą się pragnienia bezpieczeństwa, bezproblemowości i zadowolenia oraz indywidualnie wypracowane reguły ich realizowania poprzez „układanie się” z otoczeniem. Rafał Drozdowski zwrócił uwagę na napięcie między potrzebą posiadania praktycznego miejsca, w którym te pragnienia będą konkretyzowane, a potrzebą jego oswajania, odciskania na nim swego piętna ${ }^{18}$. W przypadku zakładów, w których świadczy się usługi dla ludności, reguły te rzutują na budowanie kontaktów i więzi z klientami oraz otoczeniem. Reguły te wpływają także na działania wytwarzające taką przestrzeń, która stanie się azylem dającym właścicielowi określone uprawnienia. Dlatego spojrzenie pani Marii na ulicę Wschodnią, jej emocje wiążące się z przestrzenią ulicy, nie mogły być statyczne, musiały zależeć od sytuacji i wpasowywać się w interpretację sytuacji. Musiał zatem nadejść czas kreowania relacji z ulicą, które były dla niej znaczące, służyły jej celom. Kiedyś, idąc Wschodnią, dostrzegała przede wszystkim ludzi, którzy „stali po bramach, takich pijących i niepijących, handlujących wódką". Z czasem obie strony przywykły do swej obecności i swego rytmu, można nawet mówić o pewnej zażyłości między nimi, w wyniku której krajobraz Wschodniej (północny fragment ulicy - od Pomorskiej do Rewolucji; odcinek południowy ulicy nigdy nie był dla pani Marii znaczący) zostaje obdarzony funkcją chroniącą i przeistacza się w świat udomowiony:

\section{Bała się pani tych w bramie? Przecież wiedzieli, co pani robi na Wschodniej.}

Wszyscy [stojący w bramach] wiedzieli, że ja tu pracuję. I pilnowali jak była potrzeba. Wtedy, co mi tę szybę wybili, to ci z bram sąsiednich pilnowali mego zakładu. Całą noc

\footnotetext{
${ }^{17}$ Nawiązuję do opisanej przez Ryszarda Kapuścińskiego nierozerwalności ludzi i krajobrazu w Ghanie. Kapuściński 1998, s. 9.

${ }^{18}$ Drozdowski 2010, s. 17.
} 
stali i pilnowali. Przecież złodziej swego nie okradnie, to nie honor byłby. Wtedy ktoś wybił szybę - pewnie pijana młodzież, co tędy przechodziła. Zresztą tu często przyjeżdżali taksówkami po wódkę. Po bramach trzymali ją. Ja to też znam z opowieści taty. Wystarczyło wyjść z taksówki, to już do człowieka podchodzili. A jak mi wybili szybę, to pilnowali. To był czas, gdy nie trzeba było krat zakładać, nie trzeba było wtedy wystawy sprzątać na noc. Wtedy po prostu gasiło się światło i się wychodziło z zakładu. Dopiero później rozpoczęły się czasy sejfów, krat, alarmów.

Dystynkcja bezpieczeństwa przestała działać, gdy w okolicy rozpoczęły się kradzieże zakładów i sklepów. Sprawcy wybijali w nocy szyby wystawowe lub wyłamywali drzwi wejściowe od zaplecza. Zdarzało się też, że wchodzili do zakładów za dnia, w godzinach pracy. Rzemieślnicy podjęli więc dodatkowe działania zabezpieczające - zakładali kraty na wystawy i drzwi wejściowe, zamurowywali wejścia do pomieszczeń od zaplecza.

Kraty, alarmy i sejfy są elementami wprowadzanymi nie tylko w celu zarządzania przestrzenią zakładów, ale też wchodzą w obręb praktyk przestrzennych zróżnicowanych indywidualnie, przyczyniając się do ustalenia nowych relacji i nowego porządku. To środek poprzez który reprodukuje się społeczny porządek, o czym pisze Marek Krajewski, podkreślając jego trójkierunkowe odtwarzanie: „z jednej strony redukują one nieskończoną wielość możliwych wariantów działania do tych, które reprodukują porządek, z drugiej - umożliwiają praktykowanie ładu, które same konstytuują, z trzeciej zaś - narzucają naszej wyobraźni ramy, które sprawiają, iż nie wszystko wydaje nam się możliwe"19. Innymi słowy, pełnią rolę stabilizującą, ograniczając dostęp i wzmacniając bariery (drzwi, okno) między przestrzenią prywatną (zakład rzemieślniczy) a przestrzenią publiczną (ulica), ponadto umożliwiają sprawowanie kontroli nad własnym miejscem. Własne miejsce to „pojemnik” zawierający wszystko, co niezbędne do praktykowania tego, co Krajewski nazywa „reżimami codzienności”, a więc maszyny, narzędzia, części zapasowe do napraw mechanizmów, ale też sposoby z ich korzystania, nawyki, upodobania, zbiory reguł, jak i oparte na nich aktywności itd. ${ }^{20}$.

W oswojonym otoczeniu ludzie zwracają szczególną uwagę na siebie i rzeczy zwłaszcza wtedy, gdy coś ulegnie zmianie. Przestrzeń przeistacza się wtedy w arenę interakcji, działań - nie tyle patrzenia, lecz robienia czegoś, co często umożliwia wejście ze środowiskiem w ściślejsze relacje. Egzemplifikacją jest reakcja pani Marii na sytuację zaistniałą przed jej zakładem; pokazuje ona tym samym, jak emocje kształtują codzienne kontakty:

Chodzą ci młodzi, kłaniają się, znamy się z widzenia, ale nigdy nie dochodziło do bliższych kontaktów. Lecz raz zdarzyła się taka sytuacja. Tu mam takiego chłopaka - tak około trzydziestki, może nawet mniej. Kiedyś przyszedł taki pijany, usiadł mi tu na schodach. Znałam

\footnotetext{
${ }^{19}$ Krajewski 2013, s. 56.

${ }^{20}$ Krajewski 2013, s. 136 i nast.
} 
jego rodziców, mieszkali tu na Rewolucji. Ojciec nie żyje, pracował na Wschodniej jako szewc. Matka sympatyczna, teraz wyprowadziła się do bloków, znalazła sobie faceta. Pytam go: <A ty, co tu robisz? Jakbyś był moim synem, to bym ci wytłukła. Chodź, cię odprowadzę. Albo właź do samochodu, to odwiozę. Wyspać się i nie łazić mi tutaj, pijaku jeden>. Ale nie do wszystkich tak powiem. Wzięłam i go odwiozłam do domu. Nie wiem na czym to polega, że tego chłopaka samego zostawili. Sam sobie nie pomoże. Później jak go widziałam na ulicy, to uśmiechał się. I tutaj takich jest wielu. Jak chcą tak piją, nie potrafią się odcią́ od tego środowiska tutaj. Widzę niektórych - jak stąd odeszli, to wyszli na prostą. Przychodzą tu nieraz, na ulicę. Inaczej już wyglądają, inne ubrania, inne twarze, inne ruchy, nawet coś miłego zagadną - i mnie to cieszy, że zaczynają żyć inaczej. Mnie tego chłopaka jest bardzo szkoda. Jest w wieku mojego syna.

Można zatem rzec, że zadomowienie przestrzeni polega na tym, że staje się ona wypadkową ludzkich działań i sposobów bycia w niej, zaś działania są związane nie tylko z samym charakterem przestrzeni lub z tym, co się w niej wydarza, lecz także z wywołanymi przez miejsce odczuciami i wspomnieniami.

„Pojęcie <zadomowienia> (bome making) przyciąga naszą uwagę do tego, co robimy, aby w świecie <czuć się jak w domu>" - napisał Tim Edensor ${ }^{21}$. Mary Douglas wykazała, że dom wymaga stałych wzorów aktywności i odpowiednich struktur w czasie. Z tego punktu widzenia dom jawi się jako panowanie przestrzeni nad czasem, a „porządek dnia stanowi infrastrukturę wspólnoty"22.

Zadomowiać przestrzeń, to znakować ją jako własną, poddawać działaniom mającym ją oswoić, nadać indywidualne piętno i wyjątkowość. Jednakże ta wyjątkowość, jak piszą socjolodzy w odniesieniu do domu, ma swoje granice, co znaczy, że nie wykracza ona poza „normalną oryginalność”23. Pani Bożena (czapnictwo, Wschodnia 57) poddała przestrzeń pracowni zabiegom aranżacji, nadając jej charakter galerii. Pracownię czapniczą potraktowała jak „miejsce, które należy stworzyć” ${ }^{4}$, podejmując, jakby powiedział de Certeau, jego „aktywne praktykowanie”25. „Nakrycia głowy zostają, to jest baza, natomiast wśród nich pojawiają się inne elementy, którymi się zajmuję od lat, czyli malarstwo, czyli jakieś tam działania plastyczne [kończyła liceum plastyczne i łódzką ASP - G.E.K]" - opowiadała. Rozstawia zatem w zakładzie namalowane przez siebie obrazy, układa między czapkami wykonaną przez siebie biżuterię. Właściciele kamienicy w pracowni wymienili okna i drzwi, pozwolili jej podczas remontu wybrać płytki na podłogę i kolor farby na ściany. Licząc na to, że mieszkańcy Wschodniej wpiszą się w jej

\footnotetext{
${ }^{21}$ Edensor 2002, s. 80.

${ }^{22}$ Douglas 1991, s. 301.

${ }^{23}$ Drozdowski 2010, s. 18.

${ }^{24}$ Termin Lesley Johnson, która tak nazwała aktywności australijskich kobiet we wnętrzach swych domów. Johnson 1996, s. 461.

${ }^{25}$ de Certeau 2008, s. 117.
} 
sposób konstruowania przestrzeni, oznaki swego statusu zamieściła na szybach witryn tak, by były widziane na zewnątrz, od ulicy: „Strefa Sztuki / Fszysstko na sprzedaż / art. plastyk B. Markowicz / Art. Zone / Czapki”. Ponadto wymalowała elewację, do kraty przymocowała zielone i pomarańczowe litery tworzące słowo „tak”, przed sklepem postawiła dizajnerski rower, a tuż przed schodami, na chodniku, rozwinęła kawałek dywanu, który - jak w domu wycieraczka przy drzwiach - zachęca do wytarcia butów. Poprzez te działania pani Bożena sprawuje kontrolę nad fragmentem przestrzeni za pomocą przedmiotów - znaczników tożsamości, które są jednocześnie próbą zdefiniowania siebie w miejscu ${ }^{26}$. Można zatem powiedzieć za Małgorzatą Dymnicką, że możliwa jest rekonstrukcja domu w postaci reintegracji znajomych, rutynowych czynności odtwarzanych w dowolnej przestrzeni ${ }^{27}$, a praktyki pani Bożeny przekonują, że pomocą w zadomowieniu stają się dekoracyjne artefakty.

Pani Bożena tak mówiła o swoich działaniach:

Rzeczy, które mają być ładne lub piękne, to mieć na tej ulicy jest trochę bez sensu. Wydają się być jakimś wyrzutem wobec tych ludzi i wobec tego, co się tu dzieje. Nawet myślałam, że po prostu nie wypada. Ale później pomyślałam, że nie, właśnie przeciwnie, właśnie dlatego, żeby pokazać, że istnieje inny model życia, że może być coś ważne w życiu, i że jest coś, co jest ładne. Nie tylko, by usiąść i pić, i sprowadzić swoje potrzeby do tego. Pokazać, że ja się z tym nie zgadzam.

Pani Bożena mocno identyfikuje się z ulicą Wschodnią. Dekoracje, które umieszcza na zewnątrz pracowni, na elewacji i na chodniku, w rzeczywistości zawierają duży ładunek emocjonalny skierowany na akcentowanie jedności z ulicą. Marianne Gullestad pisała, że domy bez zewnętrznych dekoracji, detali czy wizualnych bodźców są „nieme” lub „mówią” niewiele, a wysyłana przez nie wiadomość jest monotonna i nudna ${ }^{28}$. Kamienica przy Wschodniej 57 otrzymała kolorową i wesołą dekorację, która sprawiła, że fragment jej elewacji wyodrębnił się z otoczenia, stał się widoczny, przyciąga wzrok, budzi zainteresowanie. Podobnie działa na zmysły zewnętrzna dekoracja zakładu pani Elżbiety (Ela Natura - projektowanie odzieży, Wschodnia 59). Wygląda to tak, jakby substancja materialna ulicy Wschodniej pod numerami 57 i 59 otrzymała opakowanie, o którym Marek Krajewski pisze, że „pobudza ciekawość, „budzi pragnienia”, „zwraca uwagę na produkt, informuje, edukuje, zachęca, inspiruje i poucza”29. W ten sposób głos działających po sąsiedzku właścicielek zakładów rzemieślniczych włączył się w proces nadawania nowego znaczenia ulicy kojarzonej dotąd z zaniedbaną przestrzenią, ubóstwem i różnymi formami wykluczenia społecznego. Również w ten sposób obie panie

\footnotetext{
${ }^{26}$ Zob. Cresswell 2009; Dant 2007.

${ }^{27}$ Dymnicka 2011, s. 49.

${ }^{28}$ Gullestad 1992, s. 77.

${ }^{29}$ Krajewski 2013, s. 215, 220.
} 
biorą fragment Wschodniej w swoje posiadanie i zadomowiają ją, nadając jej nowe symboliczne konfiguracje.

Według Doreen Massey tożsamość miejsca jest konstruowana z kompozycji więzi i stosunków społecznych tkanych $\mathrm{w}$ trakcie wspólnie spędzanego czasu ${ }^{30}$. Jacek Kurczewski, pisząc o domu, zwraca uwagę na proces udomowiania przestrzeni różnych instytucji:

Panie przynosiły w słoiczkach pierożki, gołąbki i inne domowej roboty przysmaki, którymi - po podgrzaniu na ukrytej między papierami płytce elektrycznej - dzieliły się między sobą nie wykluczając i mnie, choć dawały mi zawsze odczuć, że jestem gościem, a nie pełnoprawnym uczestnikiem wymiany. Innym, już standardowym elementem, była herbata, której gotowanie było oficjalnym uzasadnieniem wspomnianej już płytki, służącej w zimie jako dodatkowy piecyk ${ }^{31}$.

Udomowianie miejsc pracy w wyniku wzajemnego goszczenia było powszechne w czasach PRL, o czym można przeczytać $\mathrm{w}$ wielu wspomnieniach ${ }^{32}$, nie ominęło też zakładów rzemieślniczych na Wschodniej. Rzemieślnicy podejmowali poczęstunkiem osoby z zaprzyjaźnionych w okolicy warsztatów i sklepów z okazji imienin i świąt, również wtedy, gdy ktoś z nich wpadł tylko na chwilę, by opowiedzieć lub skomentować jakieś wydarzenie. Wszyscy na zapleczu mieli - jak w domu - sztućce, kubki, szklanki, kieliszki, również garnki i maszynki elektryczne lub podłączone do butli gazowej.

Pan Zbyszek (zegarmistrzostwo, Wschodnia 27) przedstawił topografię swych wędrówek po Wschodniej i opisał fragment ulicy, który objął praktykami przestrzennymi. Opowiadając o spotkaniach towarzyskich, wymienił konkretne adresy: miejsca znajdujące się naprzeciwko, tuż obok, po sąsiedzku jego warsztatu, również o kilka przecznic dalej. Usytuował on wydarzenia przestrzennie, przez co przestały być czystą abstrakcją, albowiem - jak pisała Barbara Szacka - „Poprzez związanie z określonym miejscem potwierdzona zostaje jego [wydarzenia] prawdziwość i realność”33.

Pan Zbyszek opowiada o praktykach, za pomocą których doświadczał przestrzeni Wschodniej, zadomawiał ją. Praktyka chodzenia, sposoby bycia w przestrzeni i cielesnego, fizycznego działania w niej, uwidaczniały „społeczne <zaangażowanie>” (termin Pierre’a Mayola), prowadząc do powstawania różnych form współdziałania, tworząc przestrzenne relacje i więzi, pogłębiając związki już istniejące. Przez tę praktykę pan Zbyszek tworzył prywatną i podmiotową mapę ulicy oraz okolic jako ich użytkownik w opozycji do struktury urbanistycznej. Formuła Michela de Certeau, że akty chodzenia

\footnotetext{
${ }^{30}$ Massey 2005, s. 55-60.

${ }^{31}$ Kurczewski 1997, s. 10.

32 Np. Wedel 2007.

${ }^{33}$ Szacka 2006, s. 143.
} 
są dla przestrzeni, w której ta czynność się odbywa, tym, czym akty mowy dla języka ${ }^{34}$, zyskuje w opowieści pana Zbyszka wyjątkową materialność. Mapa ulicy Wschodniej i okolic jego autorstwa „utkana” jest z zakładów rzemieślniczych i sklepów. Zakłady szewskie na Wschodniej i na Jaracza, warzywniak na Wschodniej oraz sklep obuwniczy Chełmek na Nowotki stanowiły ośrodki życia towarzyskiego, w którym zegarmistrz aktywnie uczestniczył, były centrami wymiany informacji i usług, znacznikami jednego z etapów jego życia. Do tych miejsc można było wpaść bez zapowiedzi, pory odwiedzin wyznaczały godziny pracy, które w miarę potrzeb przesuwano do późnych godzin, często spotykało się tam innych znajomych. Lecz przede wszystkim opowieść pana Zbyszka kieruje słuchacza na ludzi. Szewc Czesio Pierzak, Jasiek - kierownik sklepu obuwniczego oraz Krysia - właścicielka warzywniaka to osoby, które wspomagały utrwalanie poczucia zadomowienia ulicy, bo były uwikłane w topografię Wschodniej i kształtowały topografię doświadczania ulicy przez zegarmistrza.

Kiedy zostały zlikwidowane miejsca definiujące więź, powstawały nowe przestrzenie i ulegały zmianie społeczności. I tak dziś, tam gdzie były dodatki szewskie prowadzone przez Czesia Pierzaka są delikatesy, sklep Pierożek zajął przestrzeń po warzywniaku Krysi Wilczyńskiej, a w miejscu Chełmka jest sklep spożywczy. Jednak pozostało przywiązanie do miejsc, które kiedyś były ramą dla codziennych aktywności pana Zbyszka, a dziś stanowią symboliczną więź między nim a miejscami i ludźmi podtrzymywaną poprzez wspominanie i rozmowę.

A dziś też tak się gościcie? - pytam pana Zbyszka.

- Dziś już nie ma takich znajomości i takich ludzi. Młodzi przychodzą do pracy, potem zamykają i pędzą do domu, z nikim się nie zaznajamiają. Nikt nie ma czasu, pędzi. Kiedyś to trzeba było pogadać, wypić, przy okazji sprawy pozałatwiać: a to lodówkę, a to ubranie, a to popchnąć jakąś sprawę przez znajomego kolegi. Dziś nie są potrzebne takie znajomości, bo wszystko jest. Ja tu siedzę i czekam na klientów. Nie mam do kogo iść, bo wszyscy dookoła zamykają. Fryzjerki, co są po sąsiedzku, codziennie robią mi kawę. Klienci dziwią się, że one tak robią mi tą kawę. Ano robią, bo przy okazji ze starym człowiekiem pogadają. Opowiadam im jak tu kiedyś wesoło było, jak się żyło.

W jego opowieści wybrzmiewa strukturalne zróżnicowanie punktów handlowych na Wschodniej. Oprócz zakładów rzemieślniczych znajdowały się tu sklepy spożywcze, z rybami, pieczywem, mięsem i warzywami stanowiące fundament formowania się relacji sąsiedzkich. Relacje te cechowała przewidywalność i powtarzalność, wzmacniając proces zespolenia z ulicą. Kupując u tego samego rzeźnika czy piekarza, ludzie zadomawiali się w jej przestrzeni, poprzez codzienne praktyki konstytuowali miejsce, które z kolei stawało się tłem ich emocji. Badacze podkreślają, że emocje są zrozumiałe jedynie

\footnotetext{
${ }^{34}$ de Certeau 2008, s. 117.
} 
w kontekście konkretnego miejsca, i odwrotnie, miejsce musi być jakoś odczuwane, by mogło mieć znaczenie. Wartość miejsca kształtuje się tylko poprzez emocjonalną relację pomiędzy ludźmi i przestrzeniąa ${ }^{35}$. Przywołam fragment narracji pani Marii (zegarmistrzostwo, Wschodnia 33):

W większości to tutaj robiłam zakupy. Przecież to tutaj były konsumy. Wrzucałam w samochód i jechałam do domu. Znaliśmy się przecież wszyscy. To na przykład do mięsnego rano się wpadło: - Zostaw mi tego, tamtego - mówiłam. Oprócz konsumów był też taki mały mięsny, z wędlinami - jak ona się nazywała, co go prowadziła? Ona już nie żyje. Jej mąż był policjantem. Jak ja tu przyszłam w osiemdziesiątym siódmym, by pomóc tacie, to ona już była. Były wtedy kartki, ale zawsze coś dla nas na boku odłożyła, więc u niej kupowałam. Wspomagaliśmy się wtedy tu, na Wschodniej. Ktoś mi dawał powiedzmy kartki na cukier, a ja mu oddawałam na papierosy czy alkohol.

Tu naprzeciwko był taki duży sklep z AGD. Tam, gdzie jest biblioteka teraz. Czy może tam dalej, gdzie są tanie rzeczy? Tu nam dobrze było z tym sklepem. Jak mieli dostawę, to najpierw wśród swoich rozprowadzali towar. Zawsze człowiek coś potrzebował przecież i zawsze był obsłużony należycie.

(...)

Tu na rogu Rewolucji był ryneczek i ludzie sprzedawali tam swoje wyroby. Taki ryneczek był też przy Jaracza w takiej wnęce. Tam chyba są jakieś kioski poustawiane. Była piekarnia bardzo duża na Wschodniej między Włókienniczą a Rewolucji. Kupę lat oni byli. To chleb tu kupowałam zawsze do domu, zawsze mi zostawiali, już nie myślałam, gdzie szukać. Mięso w konsumach albo u tej Krysi w warzywniaku. Tutaj też był warzywniak, gdzie stomatologia. Najpierw prowadziła Janeczki teściowa, potem Janeczka wzięła - już nie żyje z dziesięć lat. Dużo było tych warzywniaków. Apteka na rogu z Włókienniczą - rzut beretem i jaka wygoda była. Wtedy też nie było łatwo $z$ lekarstwami przecież. Panie $\mathrm{z}$ apteki zawsze o mnie zadbały, wielokroć ratowały w biedzie. Poza tym myśmy się znali, rozmawiali ze sobą, opowiadali, wpadaliśmy do siebie a to na herbatę, a to złożyć życzenia, pogadać. A to zobowiązywało do świadczenia sobie pomocy.

Jak widać, ulica nie jest po prostu fizycznym bytem, lecz uzyskuje wartość i znaczenie symboliczne. Tak jak niektórzy w dzieciństwie nauczyli się „habitusu” Wschodniej, tak wszyscy później szybko rozpoznali i przywłaszczyli zbiór reguł obowiązujących w peerelowskich latach 70. i 80. Janine Wedel czy Wojciech Pawlik zwracają uwagę, że podobnie jak w przypadku rytuałów opisywanych przez Marcela Maussa, w tym łańcuchu świadczeń chodziło o skomplikowaną, gęsto splecioną siatkę powiązań, zobowiązań i gestów przekraczających system PRL, opierających się na bezpośrednich kontaktach, relacji wzajemności i wymiany ${ }^{36}$. Wspomnę przeprowadzoną przez Mary Douglas

${ }^{35}$ Kearney, Bradley 2009, s. 79, za: Gnieciak 2011, s. 63.

${ }^{36}$ Wedel 2007, Pawlik 2004. 
analizę domu jako formę „ekonomii daru”, czyli podtrzymywanego nieustannie wszechstronnego systemu wymiany ${ }^{37}$, czy badania Tomasza Rakowskiego widzącego w takich postawach aktywne podejście do rzeczywistości i urządzanie się w niej ${ }^{38}$.

Z kulturowego punktu widzenia ulica jest przestrzenią wielowarstwową, eksponującą różny stopień ciągłości i nieciągłości, mającą wiele wymiarów i znaczeń dla konkretnych osób i wspólnot, jest skonstruowana i doświadczana jak materialny artefakt i obszar relacji społecznych wytwarzanych przez różne czynności. Przedstawione praktyki zadomowiania Wschodniej pokazują, jak określone miejsca w obrębie ulicy stają się obszarem ludzkiego zaangażowania. Ich zadomowianie jest procesem, podobnie jak niekończącym się procesem jest konstruowanie miejsca przez ludzkie aktywności, w wyniku czego miejsce nigdy nie jest tworem statycznym, zawsze się staje ${ }^{39}$.

\section{Bibliografia}

Benedyktowicz D., Benedyktowicz Z., 1992, Dom w tradycji ludowej, Wiedza o Kulturze, Warszawa.

Buczyńska-Garewicz H., 2006, Miejsca, strony, okolice. Przyczynek do fenomenologii przestrzeni. Universitas, Kraków.

de Certeau M.,2008, Wynaleźćcodzienność. Sztukidziatania, przeł.Thiel-Jańczuk K., Wydawnictwo UJ, Kraków.

Cresswell T., 2009, Place, Elselvier, Oxford. https://booksite.elsevier.com/brochures/hugy/ SampleContent/Place.pdf

Czermińska M., 1978, Dom w autobiografi i powieści o dzieciństwie, [w:] Głowiński M., Okopień-Sławińska A. (red.), Przestrzeń i literatura, Wrocław, s. 229-252.

Dant T., 2007, Kultura materialna w rzeczywistości spotecznej, przeł. Barański J., Wydawnictwo UJ, Kraków.

Davidson J., Milligan Ch., 2004, Embodying Emotion Sensing Space: Introducing Emotional Geographies, "Social and Cultural Geography”, vol. 5, no 4, s. 523-532. https://www.researchgate.net/profile/Christine_Milligan/publication/249005951_Embodying_Emotion_

Sensing_Space_Introducing_Emotional_Geographies/links/54ae94c20cf21670b3585e4e/ Embodying-Emotion-Sensing-Space-Introducing-Emotional-Geographies.pdf

Douglas M., 1991, The Idea of a Home. A Kind of Space, "Social Research", no 1 (Spring), s. 287-307. https://is.muni.cz/el/1423/podzim2011/SAN236/um/27590952/Douglas_ Idea_of_Home_A_Kind_of_Space_SR_090301.pdf

\footnotetext{
${ }^{37}$ Douglas 1991, s. 302-306.

${ }^{38}$ Rakowski 2009.

${ }^{39}$ Cresswell 2009, 7-8.
} 
Drozdowski R., 2010, Formy zamieszkiwania. Kilka refleksji pobadawczych, [w:] Wołyński P. (red.), Formy zamieszkiwania domostwa w obrazach - poznaniaków portret zbiorowy, Poznań, s. $15-20$.

Dymnicka M., 2011, Od miejsca do nie-miejsca, „Acta Universitatis Lodziensis. Folia Sociologica”, vol. 36, s. 35-52.

Edensor T., 2002, Tö̇samośc narodowa, kultura popularna i życie codzienne, przeł. Sadza A., Wydawnictwo UJ, Kraków.

Gnieciak M., 2011, Emocje i pamięć: przyczynek do "geografi emocjonalnej" w ramach analizy wywiadów mieszkañców osiedli postrobotniczych w Będzinie i Rudzie Ślaskiej. „Górnośląskie Studia Socjologiczne. Seria Nowa", 2, s. 60-89.

Grotowska-Leder J., 1999, Eódzkie enklawy biedy: aspekt przestrzenny i dynamiczny, [w:] Warzywoda-Kruszyńska J. (red.), (Żyć) Na marginesie wielkiego miasta, Instytut Socjologii UŁ, Łódź, s. 55-76.

Grotowska-Leder J., 2002, Fenomen wielkomiejskiej biedy. Od epizodu do underclass, Wydawnictwo UŁ, Łódź.

Gullestad M., 1992, The Art of Social Relations. Essays on Culture, Social Action and Everyday Life in Modern Norway, Scandinavian University Press, Oslo.

Johnson L., 1996, As Housewives We are Worms: Women, Modernity and the Home Question, "Cultural Studies" no 3, p. 449-463.

Kapuściński R., 1998, Heban, Czytelnik, Warszawa.

Kearney A., Bradley J. J., 2009, 'Too strong to ever be there': place names and emotional geographies, "Social and Cultural Geography", 10, 77-94.

Krajewski M., 2013, Sq w życiu rzeczy. Szkice z socjologii przedmiotów, Fundacja Bęc Zmiana, Warszawa.

Kurczewski J., 1997, Dom i jego przeciwieństwa. Szkic zagadnienia, [w:] Dąbek-Wirgowa T., Makowiecki A.Z. (red.), Obraz domu w kulturach stowiańskich, Uniwersytet Warszawski, Wydział Polonistyki, Warszawa, s. 7-14.

Massey D., 2005, For Space, Sage, London. https://selforganizedseminar.files.wordpress.com/ 2011/07/massey-for_space.pdf

Matthews H., 2003, The Street as a Liminal Space. The Barbed Spaces of Childhood, [w:] Christensen P., O'Brien M. (eds.), Children in the City. Home, Niegbbourhood and Community, Routledge, London, s. 101-117. http://www.shahrsazionline.com/wp-content/uploads/2016/01/Chil dren-in-the-Citywww.shahrsazionline.com_.pdf

Pawlik W., 2004, Ekonomia życia codziennego spoteczności lokalnej, [w:] Kurczewski J. (red.), Umowa o kartki, Wydawnictwo TRIO, Warszawa, s. 139-167.

Pink S., 2008, An Urban Tour: The Sensory Sociality of Ethnographic Place-Making, "Ethnography", vol. 9, pp. 175-196. file:///C:/Users/user/Downloads/Pink,\%20S-\%202008\%20An\%20 urban\%20tour\%20(1).pdf

Rakowski T., 2009, Łowcy, zbieracze, praktycy niemocy. Etnografia cztowieka zdegradowanego, Słowo/obraz terytoria, Gdańsk. 
Rapior W., 2012, Krajobraz, pośród którego stoimy. Nauki spoteczne, praktyka artystyczna i chodzenie, [w:] Łuczak M.J. (red.), Przestrzeń we wspótczesnych naukach spotecznych, Poznań, s. 147-161. Saryusz-Wolska M., 2011, Spotkania czasu z miejscem. Studia o pamięci i miastach, Wydawnictwo UW, Warszawa.

Szacka B., 2006, Czas przeszty - pamięć - mit, Wydawnictwo Naukowe „Scholar”, Warszawa.

Warzywoda-Kruszyńska W., 2013, Intergenerational Transmission of Poverty: a Challenge for Poland, "Baltic Region", no 3, s. 59-66. https://doi.org/10.5922/2079-8555-2013-3-6

Wedel J.R., 2007, Prywatna Polska, przeł. Kowalski S., Wydawnictwo Trio, Warszawa. 
